УДК 373 - 056.2/3(091)

DOI: https://doi.org/10.54662/veresen.2.2021.11

Оксана Коноз,

ORCID iD 0000-0003-0443-9531

аспірантка кафедри дошкільної освіти Миколаївський національний університет імені В. О. Сухомлинського вул. Нікольска, 24, 54000, м. Миколаїв, Україна konozoksana77@gmail.com

\title{
РОЗВИТОК ІНКЛЮЗИВНОЇ ОСВІТИ В УКРАЇНІ: ОСОБЛИВОСТІ ПРОВЕДЕННЯ ВСЕУКРАЇНСЬКИХ ЕКСПЕРИМЕНТІВ 2001-2019 рр.
}

У статті йдеться про передумови впровадження та реалізацію інклюзії в Україні на початку XXI століття через проведення Всеукраїнських науково-педагогічних експериментів. Проведено порівняльний аналіз трьох науково-педагогічних Всеукраїнських експериментів: 1) навчання осіб з особливими освітніми потребами в інтегрованих умовах 2001-2007 рр. "Соціальна адаптація та інтеграція в суспільство дітей з особливостями психофізичного розвитку шляхом організачї̈ їх навчання у загальноосвітніх закладах»; 2) 2008-2013 рр. "Соціальна адаптаиія та інтеграчія в суспільство дітей, які потребують корекиії фізичного (або) розумового розвитку, иляхом запровадження їх інклюзивного навчання» для визначення результатів та їхнього впливу на розвиток інклюзивного навчання в Україні; 3) 2016-2019 рр. «Розвиток інклюзивного освітнього середовища в Запорізькій області».

Описано мету проєктів: зміџнення ставлення уряду, закладів освіти та неурядових організачій, механізми регулювання, законодавчі нормативні документи впровадження інклюзивного навчання. Указано організаторів-партнерів, напрями, фінансування, результати. Доведено динаміку росту кількості залучених дітей з особливими освітніми потребами (ООП), інклюзивних шкіл, класів (груп), збільшення асистентів учителів. Наведено приклади модернізачії освітньої галузі через розбудову інклюзивного освітнього середовища та проблеми розвитку: навчання педагогів, громадська думка, неготовність педагогічних працівників до роботи з особами з ООП, недостатнє фінансування, брак орієнтування, компетентностей, необхідних для подальшого самостійного життя, у програмах дітей для ООП, необізнаність щцодо вітчизняного та зарубіжного досвіду роботи з особами з ООП. Наукова новизна розвідки полягає в порівнянні модернізацій та реформ в освітній галузі із запровадженням інклюзивного навчання, виробленні механізмів надання послуг дітям з ООП-психолого-педагогічного супроводу та корекиійно-розвиткових занять.

Ключові слова: діти з особливими освітніми потребами (ООП); інклюзивне навчання; інклюзія; модернізація; реформування.

(C) Коноз О. Б., 2021

Вступ. Актуальність дослідження. Конвенція ООН про права дитини (1989), ратифікована Україною в 1991 році, та Стандартні правила забезпечення рівних можливостей для інвалідів (1993), визнані Україною, сприяли переосмисленню суспільством сприйняття інвалідності та визнання права на якісне навчання, проживання в сім'ї, лікування, реабілітацію тощо. Визнання особистості кожної дитини, зміна філософії освіти, а саме освітньої парадигми на гуманістичну, відповідно 
до якої: «освіта для всіх, школа для всіх» (1990), відкритість суспільства ініціювали реформування освітньої системи (закони «Про освіту» 1991, 1999, 2017, 2020 та інші нормативні документи). Із 1992 року діти з інвалідністю починають навчатися за індивідуальною формою або в спеціальних класах (інтеграція), потім вступають до закладів вищої освіти. У зв'язку зі збільшенням удвічі дітей із психофізичними порушеннями (за А. Колупаєвою) дітей із легшими порушеннями інтегрують у заклади загальної освіти (стихійна інтеграція). У Свропі модернізація освіти (в Італії 90 \% дітей із ООП навчаються в масових закладах) та реформування відбувається відповідно до Саламанської декларації (1994), яка наголосила, що найкраще здобувати освіту дітям із ООП в інклюзивних закладах. Застосовуючи оригінальні модернізації освіти, європейські країни вибудовують свою модель інклюзії з урахуванням національного підгрунтя, сприймання та прийняття цієї проблеми суспільством, громадської думки тощо.

Постановка проблеми. Актуальною проблемою в сучасному суспільстві $є$ залучення дітей із особливими освітніми потребами в освітні заклади. 3 одного боку, батьки дітей із порушеннями хочуть, щоб їхні діти навчалися з однолітками та здобували якісну освіту, з іншого - адміністрація шкіл та батьки здорових дітей не готові до цих нововведень. Проблемою $є$ «залучення осіб із ООП у сільських школах» (Будяк Л. В., 2010, с. 10). Педагоги закладів загальної освіти не володіють методиками спеціальної освіти, їм важко даються інновації, не всі згодні працювати з особами 3 ООП. Неабияке зацікавлення викликає розвиток інклюзивної освіти в Україні через проведення Всеукраїнських науково-педагогічних експериментів 2001-2019 рр. щодо залучення осіб із ООП у масові заклади. Перспективами розвитку інклюзивного навчання $\epsilon$ еволюція інклюзивного суспільства, зміна громадської думки, підтримка фінансування інклюзії, навчання педагогів, розвиток інклюзивного освіт- нього середовища, упровадження принципів універсального дизайну та розумного пристосування, ознайомлення $з$ успішним зарубіжним досвідом.

Мета статті - дослідити особливості розвитку інклюзивної освіти методом порівняльного аналізу та синтезу, визначити їхній уплив на розвиток освітньої галузі. Завданням нашого дослідження $є$ :

1) визначити особливості розвитку освітньої галузі, інновації, реформування та модернізації в освітній галузі;

2) порівняти експерименти 20012019 років та визначити тенденції розвитку системи освіти, проблеми інклюзії та шляхи їхнього розв'язання;

3) дослідити динаміку росту розвитку інклюзивної освіти, охоплення інклюзивним навчанням осіб із ООП.

Аналіз останніх публікацій. Проблемі розвитку інклюзивної освіти присвятили праці такі зарубіжні та вітчизняні вчені: Т. Бут, Д. Депплер (показники інклюзії), Д. Харві, В. Мілс, Д. Джонсон (психолого-педагогічне оцінювання), Л. М. Шипіцина, Н. Н. Малафєєв (інтегративна освіта), В. В. Засенко, А. А. Колупаєва, О. М. Таранченко (розробники української моделі інклюзивної освіти), О. І. Федоренко, Т. В. Сак, Т. В. Скрипник, Н. 3. Софій, Ю. М. Найда, В. В. Тарасун (розроблення інноваційних технологій у роботі з дітьми різних нозологій) та ін.

Серед передумов проведення - інтеграційні процеси в освіті (Шипицына Л. М., 2004, с. 10), а також суспільно-політичні та соціально-економічні події: орієнтація на європейський освітній простір, перехідні умови до відкритого, демократичного суспільства, залучення осіб iз ООП до навчання за індивідуальною формою (1992) та у школи, заклади вищої освіти (ЗВО) (із 1999), створення батьками громадських організацій та шкіл для «ненаучуваних» дітей, яких система не приймала на навчання, масове відкриття реабілітаційних центрів для раннього виявлення та консультування тощо. Важливою стала робота організації «Крок за кроком», яка 3 
1996 року реалізує програму «Інклюзивна освіта», що далі разом із Інститутом спеціальної педагогіки, МОН України працює над програмою впровадження інклюзії, готується до першого експерименту.

Виклад основного матеріалу. «Інклюзія в освіті - це впровадження інклюзивних цінностей у практичну діяльність; допомога кожному відчути себе частиною цілого, уникнення практики виключення, дискримінації, наявності бар'єрів у навчанні й участі в шкільному житті; унесення змін до культури, політики і щоденної діяльності (практики) як відповідь на чинник багатоманітності» (Бут Т., 2015, c. 11). Безумовно, із визнанням демократичних та загальнолюдських цінностей, розвитком толерантності в суспільстві, соціальної реклами та проєктів успішних інклюзивних закладів покращується сприйняття осіб з ООП та збільшується їх прийняття в соціумі. «Інклюзія - це повне залучення всіх учнів до всіх аспектів навчання та шкільного життя, незалежно від наявності тих чи інших індивідуальних відмінностей» (Лорман Т., 2010, с. 1). Ще в 2001 році Т. Лорман і Т. Деппелер пояснювали явище інтеграції, акцентуючи на тому, що спеціальні класи в школах або класи в сегрегованому середовищі в масових школах - це не інклюзія. Якщо учні з ООП навчаються за іншою програмою, що за своїм змістом відрізняється від тієї, яку пропонують одноліткам, - це теж не інклюзія. І ми в цьому переконуємося. Бажання батьків дітей із ООП здобути якісну освіту - це шлях до набуття професії, до майбутнього самостійного життя. Завдання нашої освіти нині - починаючи 3 дошкільного віку забезпечити освітою всіх дітей навчанням упродовж життя, тобто безперервним навчанням. У Законі «Про освіту» інклюзивне навчання - це система освітніх послуг, гарантованих державою, що базується на принципах недискримінації, урахуванні багатоманітності людини, ефективного залучення та приєднання до освітнього процесу всіх його учасників. На нашу думку, інклюзивне навчання - це спільне навчання, здобування якісної освіти водночас із однолітками завдяки створеній особисто орієнтованій траєкторії кваліфікованими спеціалістами (наставниками, інструкторами, координаторами, корекційними педагогами, поведінковими аналітиками та ін.) в толерантному суспільстві; прийняття соціумом і життя в ньому особистим життям.

Т. Р. Кудярська зазначає, що нині проблемою $є$ недостатній рівень готовності майбутніх педагогів закладів дошкільної освіти (ЗДО) до упровадження активних форм педагогічної взаємодії в умовах інклюзивного навчання. «Найбільш ефективною формою організації підготовки майбутніх педагогів закладів дошкільної освіти є безперервна підготовка всього педагогічного колективу як команди» (Кудярська Т. Р., 2021, с. 39). Науковці пояснюють, що «труднощі становлення і розвитку інтеграційно-інклюзивного процесу в Україні лежать не тільки в економічній площині, а часто - у негативному ставленні певного кола науково-педагогічних працівників до цього процесу, хоч зараз цей процес інтенсивно розвивається у більшості країн світу; у браку досвіду, неготовності працювати з особами з ООП, у недостатньому науково-методичному забезпеченні, в універсальному дизайні в усіх сферах» (Тарасун В. В., 2017, с. 14).

У наш час реформи відбуваються здебільшого у сфері загальної середньої освіти, дошкільної освіти. Щодо вищої освіти науковці зазначають, «що визначення освітніх бар'єрів та засобів їх подолання для різних категорій студентів з інвалідністю $є$ першочерговою необхідністю для закладів вищої освіти, поширення досвіду створення ІРЦ в університетах» (Тимчик О., Жукова Ю., 2021, с. 76). Такий ІРЦ відкритий у Київському університеті ім. Бориса Грінченка у 2019 році. Згадаємо перші інтеграційно-інклюзивні процеси та експерименти.

2001 р. розпочався Всеукраїнський науково-педагогічний експеримент «Соціальна адаптація та інтеграція в суспільство дітей 3 особливостями психофізичного 
розвитку шляхом організації їх навчання у загальноосвітніх закладах» на період 2001-2007 pp. (наказ МОН України № 586 від 10 серпня 2001 року). Головною метою спільного інклюзивного навчання $\epsilon$ створення умов для особистісного розвитку, творчої самореалізації та утвердження людської гідності дітей з ООП; моделювання системи інклюзивного навчання дітей 3 особливостями психофізичного розвитку 3 наданням їм відповідної корекційно-педагогічної допомоги в традиційних масових закладах та закладах інноваційного типу, яка би передбачала створення відповідних соціально-побутових умов, кадрове забезпечення, участь батьків у навчально-виховному процесі та просвітницьку діяльність серед населення щодо дітей з особливими освітніми потребами (Колупаєва А. А., 2009, с. 98). Перед проведенням експерименту до переліку педагогічних працівників унесено посаду асистента вихователя як суб'єкта освітньої діяльності.

Науковим керівником державного експерименту призначено заступника директора Інституту спеціальної педагогіки, доктора педагогічних наук В. В. Засенка. МОН України та організацією «Крок за кроком» обрано 27 закладів у містах Києві, Славутичу, Білій Церкві, Львові, Дніпропетровську, Полтаві, Івано-Франківську, Запоріжжі, Теребовлі: три навчально-виховні комплекси, п'ять закладів дошкільної освіти і стільки же шкіл - дитячих садків, одинадцять ЗОШ, два реабілітаційних центри, одну спецшколу-інтернат для дітей зі зниженим зором із гімназійними класами. Усього залучено 178 дітей: 55 у дошкілля та 123 в початкову школу. Серед залучених учнів діти із порушенням слуху, зору, ЗПР, із тяжкими порушеннями мовлення, iз порушеннями опорно-рухового апарату та іншими порушеннями. 30 \% становили діти 3 ДЦП. Не залучено дітей із категорії «ненаучуваних».

Фондом «Крок за кроком» створено курс для підготовки вчителів-практиків та курси підвищення кваліфікації учителів, які працюють (2003). Створено 7 навчальних центрів у містах-осередках, дано 54 навчально-практичних тренінги на всеукраїнському та місцевих рівнях. Архітектурно адаптовані 5 експериментальних закладів, збудовані пандуси, здійснена реконструкція вбиралень. На базі 4-х інститутів післядипломної педагогічної освіти в Полтаві, Львові, Івано-Франківську та Білій Церкві організовано проблемно-тематичні курси. Розроблено критерії та механізми оцінювання впливу експериментальної програми на учасників, а також проведено дослідження впливу інклюзивної моделі освіти на учасників проєкту, розроблено проєкт Положення «Про інтегроване/інклюзивне навчання».

Варто додати, що у 2002 році Україна перейшла на іншу модель освіти - особисто орієнтовану, державоцентристські погляди відступили перед «людиноцентризмом», людину стали вважати головною, тому «дитиноцентризм» увійшов до головних принципів навчання. Інтегрування дітей із особливими потребами в загальноосвітній простір України як один із напрямів гуманізації всієї системи освіти, що відповідає пріоритетам державної політики, визначено в «Національній доктрині розвитку освіти в Україні у XXI столітті» (Колупаєва А. А., 2009, с. 80). Із початком експерименту відразу ж виникають потреби в реформуванні та модернізації освітньої галузі. Фахівці працюють без додаткового фінансування. Визначено проблеми в організаційних формах залучення, науково-методичному забезпеченні, законодавчій підтримці, фінансуванні. Сильними сторонами інклюзивного навчання стали: здобуття якісної освіти разом $з$ однолітками, можливість брати участь у різних видах діяльності, зростання самооцінки та самостійності, формування реалістичного світогляду, розвиток емпатії та толерантності в однолітків. Спільне навчання передбачає позитивний вплив на громадську думку через коло близьких людей: батьків, педагогів, інших членів освітнього процесу. А задля цього «школи можуть змінюватися 3 різних причин: план розвитку школи врахо- 
вує думку дітей і родини, асистенти педагога беруть участь у плануванні, організовано кімнату для батьків, система цінностей поділяється і приймається...» (Бут Т., 2015, c. 10).

Для підтримання моделі інклюзивної освіти у 2008 р. започатковано II Всеукраїнський експеримент канадсько-українського проєкту «Соціальна адаптація та інтеграція в суспільство дітей, які потребують корекції фізичного (або) розумового розвитку, шляхом запровадження їх інклюзивного навчання» (2008-2013 рр.) у межах двох пілотних областей: у Львівській області та Криму (Сімферополь), але потім долучився і Київ. Усього 67 партнерів-організацій брали участь на загальнодержавному, регіональному та муніципальному рівнях, ініціюючи зміни в соціальній, освітній, громадянській політиці. Київська область представляла загальнодержавні інтереси. Представників цієї області залучено до консультування розвитку проєкту, етапів реалізації й оцінки діяльності проєкту у трьох складових сферах - політиці, закладах освіти та громадянському суспільстві. Фінансувався проєкт Канадською Агенцією 3 міжнародного розвитку The Canadian International Development Agency (CIDA). Організаторами-партнерами проєкту виступили 11 установ Канади: Канадський Центр вивчення питань інвалідності, університети Грента Мак Юена, Манітоби, Альберти, «Вікторії» та Департамент послуг для сімей провінції Манітоби, Департамент освіти провінції Манітоби, батьківські об'єднання, Товариство жителів провінції Манітоби, Канадсько-український Альянс глухих і тих, хто слабко чує (провінція Альберти), Регіональна коаліція за інклюзивну освіту міста Едмонтон.

Як основні завдання визначено: розробити концептуальні, змістові, методологічні засади моделі інклюзивної освіти в закладах освіти різних типів для дітей дошкільного та шкільного віку у міській та сільській місцевостях, формувати нову філософію державної політики, суспільних відносин щодо дітей з ООП. Залучення дітей із «ненаучуваних категорій» сприяє наповнюваності закладів освіти різних типів відповідно до нової філософії державної політики. 24 вересня 2008 року Україна підписала Конвенцію про права осіб 3 інвалідністю, а 16 грудня 2009 року Верховна Рада України ратифікувала Конвенцію ООН про права осіб з інвалідністю і Факультативний протокол до неї (документи набули чинності з 2010 року). У зв'язку з цим Україна внесла зміни до Закону «Про загальну середню освіту», згідно з якими діти з ООП мали можливість здобувати середню освіту дистанційно, а також у спеціальних та інклюзивних закладах середньої освіти.

За офіційними даними, із 100 тисяч дітей із особливими потребами, які інтегровані в загальноосвітні школи, 45 \% складають діти з інвалідністю. За індивідуальною формою навчання здобувають освіту 10495 дітей. Ця статистика, на думку В. В. Тарасун, указує на те, що сучасна система навчання дітей з особливими потребами / інвалідністю не забезпечує проголошеного права на освіту і створює штучну ізоляцію, що призводить до зниження соціальної компетентності цих дітей та масової інституціоналізації у подальшому. Тому запровадження інклюзивних підходів у галузі освіти повністю відповідає головним демократичним засадам і цінностям, а це, так само, потребує від нашої держави формування нових підходів до освітньої політики щодо осіб з інвалідністю (Тарасун В. В., 2017, с. 25).

Результатами експерименту стали соціалізовані завдяки інклюзивному навчанню 364 учні з особливостями психофізичного розвитку, задіяно 564 батьків, 464 педагогічних працівники, що пройшли курс «Залучення дітей 3 особливими потребами», створено програму підготовки вчителів (72 години) та тренінгів (18-36 годин). Прийняттям Конвенції Україна визнала інклюзію як соціальну модель, визнала те, що проблема прийняття інвалідності це правова проблема, соціум має прилаштуватися до потреб людей із особливими 
потребами. Із 2009 року починає діяти програма «Безбар'єрна Україна» 2009-2015 pр. щодо плану заходів створення доступності та безперешкодного життєвого середовища (пандуси, ліфти тощо). У законі «Про загальну середню освіту» 2010 року виокремлено разом із дошкільними закладами новий тип закладу - інклюзивний. Ці зміни спонукають приймати закон (6 липня 2010 року) про обов'язкову дошкільну освіту для всіх дітей старшого дошкільного віку, щоб забезпечити послідовність здобуття освіти 3 урахуванням дітей із ООП. Також закріплено навчання в спеціальних класах для дітей із важкими нозологіями. Це дуже актуально, адже раніше не всі діти були охоплені навчанням, зокрема діти 3 аутизмом, синдромом Дауна, важкими формами ДЦП та іншими нозологіями вважалися «ненаучуваними».

1 жовтня 2010 року як підсумок величезної роботи з упровадження інклюзії затверджено Концепцію розвитку інклюзивної освіти, доповнено класифікатор професій посадою «асистент учителя», але поки на 0,5 ставки на клас. У закладах вищої освіти протягом 2011-2012 років створюються кафедри та лабораторії інклюзивної освіти, викладаються нові дисципліни. Така робота на загальнонаціональному, регіональному та муніципальному рівнях, вочевидь, модернізує всю освітню галузь. Інклюзивна освіта має вирішити та зайняти ті ніші в освіті на запити суспільства і громадян, які не в змозі вирішити спеціальна освіта. За статистичними даними, населення України зменшується, але спостерігається зростання людей з інвалідністю, яким потрібна реабілітація та соціалізація. За 20 років (із 1990 до 2010 років) кількість повнолітніх і неповнолітніх осіб $з$ інвалідністю збільшилася майже вдвічі - із 1,6 млн осіб у 1991 році до 2,7 млн у 2011 році (із них 165 тис. дітей з інвалідністю) і досягла 6 \% загальної чисельності населення.

Для нормативного врегулювання процесу інклюзивного навчання в системі загальної середньої освіти розроблено по- рядок «Організації інклюзивного навчання в загальноосвітніх закладах» (2011), визначена корекційно-розвиткова робота (психолого-педагогічний супровід). Для регулювання порядку впровадження інклюзивного навчання - розроблення індивідуальних програм, планів, портфоліо, адаптацій та модифікацій тощо надіслано інструктивно-методичний лист Міністерства освіти України № 1/9 384 від 18.05.12 (надсилається щорічно). Цього ж року затверджено важливість психолого-педагогічного супроводу дітей із ООП в умовах інклюзивного навчання, МОН України розроблено кваліфікаційні характеристики асистента вчителя.

Затверджено i рекомендовано навчальну дисципліну «Основи інклюзивної освіти (автор А. А. Колупаєва) з 2012/2013 навчального року запровадити в навчальному процесі 3ВО, які здійснюють підготовку педагогічних працівників за напрямами (спеціальностями) «Дошкільна освіта», «Початкова освіта», «Соціальна педагогіка» (наказ МОНМС України від 18.06.2012 року№ 1/9-456) та в інститутах післядипломної освіти. Розроблено та рекомендовано науково-методичною радою 3 питань освіти МОН молоді та спорту України підручник «Інвалідність і суспільство» для впровадження у 29 закладах вищої освіти. 2013 року В. Янукович видав Указ про затвердження Стратегії розвитку освіти до 2021 року, у якій окреслено коло нових наукових досліджень, обгрунтованого та послідовного запровадження передових науково-педагогічних технологій, раціональних і ефективних підходів до організації наукової та інноваційної діяльності у сфері освіти.

У 2012 році найбільше закладів загальної середньої освіти 3 інклюзивним навчанням було в таких областях: Дніпропетровській - 59, Київській - 92, Рівненській - 29, Автономній Республіці Крим 27 , Чернівецькій - 27, Чернігівській - 26, Полтавській -25 , Херсонській - 22, Сумській - 17.

Кількість спеціальних класів для дітей $з$ особливими освітніми потребами та 
кількість учнів у них у закладах загальної середньої освіти (без спеціальних) в Україні станом на 2009/2010-2012/2013 навчальні роки (за даними МОН України) з 539 зменшилася до 508, а кількість дітей збільшилася не набагато - із 5652 до 5 675. У них у 2009/2010 навчальному році кількість спеціальних класів - 539, учнів - 5840.

2010/2011 н. р. - 484 класи, 652 учні; 2011/2012 н. p. - 508 класів, 4845 учнів; 2012/2013 н. p. - 508 класів, 5675 учнів.

Період 2014-2016 років характеризується роботою фонду «Крок за кроком» щодо реалізації проєкту створення Інклюзивно-ресурсного центру на прикладі Дніпровського району міста Києва. За статистичними даними МОНУ, у державі протягом 2014/2015 навчального року 5675 дітей із ООП навчались у 525 спеціальних класах загальноосвітніх шкіл.

2014 року створено Фонд Президента П. О. Порошенка. Він упроваджує соціальну програму «Інклюзивна освіта - рівень свідомості нації». У 2015 році наказом МОН України передбачено введення в інклюзивних групах дошкільних навчальних закладів (ДНЗ) посаду асистента вихователя з розрахунку одна штатна одиниця на одну групу, що вирішує організаційно-педагогічні та методичні умови спільного навчання в ДНЗ.

У цілому на 2015 рік в Україні для дітей із ООП працюють орієнтовно 2 тисячі ДНЗ компенсувального (санаторні, спеціальні) та комбінованого типу, де водночас із здобуттям дошкільної освіти діти отримують корекційно-реабілітаційну допомогу. 2016 року затверджено НУШ - Концепцію «Нова українська школа», у якій підтримується інклюзивне навчання. Триває робота над Законом «Про освіту» (2017).

Національна телекомпанія України разом із Національним комітетом спорту інвалідів України розпочала спеціальний телепроєкт «Життя на рівних», що містив цикл передач, присвячених людям 3 інвалідністю. «Життя на рівних» - програма про людей із ООП на підтримку та розвиток толерантності, соціальної інклюзії, впливу на громадську думку.

Усеукраїнське громадське об'єднання «Національна Асамблея інвалідів України» проводить різноманітні просвітницькі кампанії. Воно постійно закликає рекламні агенції, телевізійні компанії, установи та організації будь-якої форми власності, а також волонтерів - фізичних осіб, приєднуватися до спільної справи щодо формування толерантного ставлення до людей 3 інвалідністю.

Додамо, що, як і за кордоном, батьки та їхні об’єднання, громадські організації виступають рушійними силами змін у законодавстві з питань реабілітації, у питаннях організації та фінансуванні реабілітаційних послуг, у питаннях формування батьківської компетентності.

Третій експеримент на регіональному рівні. Наказом Міністерства освіти i науки України від 15.07.2016 р. № 836 за ініціативи Фонду П. О. Порошенка започатковано науково-педагогічний експеримент, практичний проєкт «Розвиток інклюзивного та освітнього середовища у Запорізькій області», який підтримується Благодійним Фондом П. Порошенка і за допомогою якого вирішуються організаційні та фінансові питання. Визначено 11 експериментальних закладів (у містах, селищах, селах). Організаційне керівництво експериментальною роботою покладено на Голову Благодійного фонду та заступника МОН України П. К. Хобзея (2015-2019), наукове керівництво-ІСП - В. В. Засенко, методичне - Державна наукова установа «Інститут модернізації змісту освіти» - Ю. І. Завалевського (заступника). Здійснюється просвітницька робота, організовуються конференції, тренінги, фонд забезпечує ресурсними кімнатами інклюзивні заклади тощо. Спрямування проєкту - розроблення та апробація структурно-організаційної моделі інклюзивної освіти в закладах освіти Запорізької області та подальше використання в інших регіонах України. Мета проєкту - реалізація Закону «Про освіту щодо забезпечення права дітей та молоді з ООП на освіту та їх успішної реалізації» та відпрацювання 
фінансування, принципу «гроші ходять за дитиною». В області в 47 закладах відкрито 78 інклюзивних класів для 154 дітей шкільного віку та 20 дошкільних груп з інклюзивною формою навчання.

14 лютого 2017 року український Уряд уперше виділив субвенцію 3 державного бюджету на інклюзивну освіту в закладах загальної середньої освіти (крім шкіл-інтернатів і навчально-реабілітаційних центрів), яка спрямовується на надання додаткових психолого-педагогічних, корекційно-розвиткових занять (послуг), що визначені в ІПР дитини, а також на придбання спеціальних засобів корекції психофізичного розвитку, які дають змогу опанувати освітню програму. Постановою КМУ від 12.07.17 року № 545 «Про затвердження Положення про Інклюзивно-ресурсний центр» створюється система нових закладів підтримки та супроводу дітей із особливими потребами та розпуск ПМПК. Центри утворюються з розрахунку не більше одного на 12 тисяч дітей або на 7 тисяч дітей, які проживають на території району.

Результати експерименту: розширення інклюзивної практики, створення бази даних дітей із ООП, реалізація стратегії рівного доступу і задоволення потреб, міжгалузева взаємодія Департаментів освіти і здоров'я, закладів освіти, підготовка фахівців освітньо-корекційного та реабілітаційного профілю, створення на базі Запо- різького інституту післядипломної освіти Ресурсно-тренінгового центру інклюзивного навчання (2016) на базі кафедри реабілітаційної педагогіки та здорового способу життя, висвітлення у ЗМІ. Станом на 01.09.2017 року в Запорізькій області функціонує 121 інклюзивний заклад, що майже втричі більше порівняно 32014 2015 н. p. - 57 закладів, у 2015-2016 - 66 закладів. У 253 класах навчається 395 дітей і це в 2,5 рази більше ніж у 2015-2016 pp. У 2017 році зі 121 закладу на початок року збільшилося до 147 закладів, охоплених інклюзивним навчанням.

Держава забезпечує право дітей 3 особливими освітніми потребами на якісну освіту. Завдяки вдосконаленню нормативно-правового забезпечення упродовж останніх років кількість дітей із ООП, які навчаються в інклюзивних класах закладів загальної середньої освіти, зросла у 4,5 рази, кількість інклюзивних класів - майже у 5,0 разів, кількість шкіл із інклюзивними класами - у 3,5 рази, кількість асистентів учителя - у 6,8 рази. Відбувається зростання кількості закладів дошкільної освіти, у яких створено спеціальні або інклюзивні групи. За рік кількість спеціальних груп збільшилася на 1,0 \%, інклюзивних груп на 49,1\%. Кількість дітей у таких групах збільшилася відповідно на 1,8 \% та 97,3 \%. Удосконалюється нормативно-правова база. Водночас із розбудовою мереж опорних закладів освіти у них створюються

Таблиия 1.

Дані про дітей з ООП, охоплених інклюзивним навчанням, шкіл, асистентів учителів, інклюзивних класів.

\begin{tabular}{|c|c|c|c|c|c|c|c|}
\hline & 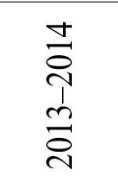 & 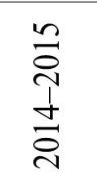 & $\begin{array}{l}0 \\
\stackrel{\circ}{\circ} \\
\text { in } \\
\stackrel{\circ}{a}\end{array}$ & 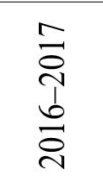 & $\begin{array}{l}\frac{\infty}{\stackrel{\infty}{*}} \\
\frac{i}{\vec{D}}\end{array}$ & $\begin{array}{l}\stackrel{a}{\vec{i}} \\
\stackrel{i}{ } \\
\stackrel{\infty}{\vec{d}}\end{array}$ & 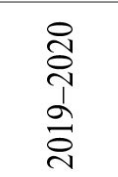 \\
\hline $\begin{array}{l}\text { Кількість учнів із } \\
\text { інклюзивних класів }\end{array}$ & $\begin{array}{l}\text { Немає } \\
\text { даних }\end{array}$ & & & 2715 & 5033 & 8417 & 13497 \\
\hline $\begin{array}{l}\text { Кількість учнів із } \\
\text { особливими } \\
\text { потребами }\end{array}$ & 2105 & 2165 & 2720 & 4180 & 7179 & 11866 & 18643 \\
\hline Кількість асистентів & 427 & 635 & 2720 & 1825 & 3732 & 7636 & 12362 \\
\hline Кількість шкіл & & & & 1518 & 2620 & 3790 & 5331 \\
\hline
\end{tabular}

Джерело складено автором самостійно за статистичними даними МОН України 
класи з інклюзивним навчанням. За чотири роки у 28,3 рази зросла кількість класів i у 5,0 разів - кількість учнів з особливими освітніми потребами, які навчаються в цих класах (Таблиця 1).

Висновки. У процесі порівняння трьох експериментів переконуємось - усі вони мали всеукраїнський масштаб, у всіх була основна і стратегічна мета - становлення і розвиток інклюзивної освіти в ЗДО, школах та ЗВО, модернізації та реформи, зміна ідеологічних орієнтацій, розвиток толерантності в суспільстві, громадянської думки, розбудова механізмів упровадження, фінансування, навчання педагогів тощо. Різницею експериментів виступили вироблені нові механізми залучення фахівців, забезпечення ними, набутий досвід упровадження, підтримка субвенціями та громадськими чи зарубіжними організаціями-партнерами, кількість залучених дітей із важкими нозологіями, масштаб поширення від міст до сіл усією Україною. Проблемою $\epsilon$ створення універсального дизайну в програмовому забезпеченні, фахівців інклюзивної педагогіки, які можуть створити особисто-орієнтовану програму для конкретного учня, адаптувати чи модифікувати іiі. Із приходом у школу починається адаптаційний період, іде час на вивчення особливостей і можливостей учня. Якщо забезпечити наступність і послідовність супроводу асистентів - наприклад, із дошкільного закладу в початкову школу або 3 початкової школи в старшу школу, тим самим полегшується адаптаційний період та обізнаність про дитину, стратегії поведінки тощо. Автор розвідки визначив позитивні та негативні тенденції розвитку інклюзивної освіти.

Із-поміж позитивних тенденцій:

1) збільшення кількості закладів, осіб iз ООП, охоплених інклюзивним навчанням і водночас зміна громадської думки; надання особам із ООП психолого-педагогічного супроводу та проведення корекційно-розвиткових занять із учителями-дефектологами;
2) отримання закладами фінансування для створення інклюзивного освітнього середовища, співпраця із громадою, меценатами, участь у проєктах;

3) підтримування інтеграції у вигляді спеціальних класів та індивідуальної форми навчання;

4) характерною для трьох ексnериментів є підтримка держави (усіх інституцій), насамперед законодавче врегулювання та модернізація в дошкільній та шкільній системах (у $3 \mathrm{BO}$ майже немає психолого-педагогічного супроводу або команди підтримки);

5) усеукраїнський масштаб уможливив швидке поширення нового механізму, як-то порядок утворення інклюзивного класу / групи, створення команди супроводу, забезпечення асистентом у ДО та школі, упровадження принципу «гроші ходять за дитиною» та ін.

Серед негативних тенденцій:

6) брак ліфтів, платформ, необладнані кабінети вчителів-дефектологів, недостатня навчально-матеріальна база;

7) необізнаність фахівців з успішним досвідом інклюзії за кордоном та їх навчання, невраховування реабілітаційної складової у школах, відсутність учителів-реабілітологів.

Важливим напрямом у наш час $\epsilon$ створення організаційно-педагогічних умов роботи вчителя-реабілітолога, учителів-дефектологів у закладі освіти як членів команди супроводу. Пріоритетами мають бути особистісні потреби кожного учасника освітнього процесу, які задоволені повністю.

Перспективи подальших досліджень убачаємо в навчанні майбутніх фахівців інклюзивної освіти, використанні інновацій, розбудові інклюзивного освітнього середовища, підвищення кваліфікації асистентів учителів та їхньому безперервному навчанні. Надзвичайно важливим $є$ забезпечення закладів методиками роботи 3 учнями 3 ООП та фахівцями, які вміють застосовувати їх на практиці . 


\title{
ЛІТЕРАТУРА
}

1. Будяк Л. В. Інклюзивне навчання в сільському загальноосвітньому закладі : авторефер. дис. на здобуття наук. ступеня к-та. пед. наук: 13.00 .03 - «Корекційна педагогіка» / Будяк Людмила Вікторівна ; Ін-т спец. педагогіки НАПН України. - К., - 2010. - 23 с. - Режим доступу: https://cuti.cc/kkgrg

2. Бут Т. Індекс інклюзії: розвиток навчання та участі в життєдіяльності шкіл: посіб./ Тоні Бут; пер. $з$ англ. - К. : ТОВ Видавничий дім «Плеяди», 2015. - 190 с. [Електронний pecypc]. - Режим доступу: http://ussf.kiev.ua/ieeditions/264/.

3. Засенко В. В. Рівний доступ до якісної освіти дітей з особливими потребами /В. В. Засенко // Кроки до демократичної освіти, 2002. - № 1. - С. 34.

4. Колупаєва А. А. Інклюзивна освіта: реалії та перспективи: монографія. / Колупаєва Алла Анатоліївна, Київ : «Самміт-Книга», 2009. - 272 с. [Електронний ресурс]. - Режим доступу: https://www.studmed.ru/kolupayeva-aa-nklyuzivna-osvta-realyi-taperspektivi_7ff11de2f67.html.

5. Колупаєва А. А. Інклюзивна освіта як модель соціального устрою. Особлива дитина: навчання і виховання, 2014. - № 2. - С. 7. [Електронний ресурс]. - Режим доступу: https://core.ac.uk/download/pdf/159118815.pdf.

6. Кудярська Т. Р. Експериментальне дослідження сформованості готовності майбутніх педагогів закладів дошкільної освіти до впровадження активних форм педагогічної взаємодії в умовах інклюзивного навчання / Т. Р. Кудярська / Herald Pedagogiki. Nauka i Praktyka. - 2021. - № 67. - ISSN: 2450-8160.

7. Лорман Т. Інклюзивна освіта. Підтримка розмаїття у класі : практичний посібник / Лорман Т., Деппелер Д., Харві Д. - Київ : СПД-ФО Парашин I. С., 2010. - 296 с.

8. Національна доктрина розвитку освіти в Україні у 21 столітті. Програма підтримки вироблення стратегії реформування освіти, Київ: Міжнародний. Фонд «Відродження», 2001. - С. 2-6. [Електронний ресурс]. - Режим доступу: https://zakon.rada.gov.ua/ laws/show/347/2002\#Text.

9. Тарасун В. В. Основи теорії і практики логодидактики : підручник для вищих навчальних закладів / В. В. Тарасун. - К. : «Каравела», 2017. - 316 с.

10. Тимчик О. і Жукова Ю. Формування інклюзивного простору в сучасному університеті : індивідуалізація та уніфікація. OD, вип. 32, вип. 1, с. 69-86, Лют.2021.DOI: https:// doi.org/10.28925/2312-5829.2021.1.5.

11. Шипицына Л. М. Интеграция детей с ограниченными возможностями здоровья / Л. М. Шипицына // Воспитание и обучение детей с нарушениями развития, 2004. - № 2. - C. 7-10.

12. Jonson J., Mill C., Muller W. Social Class and Educational Atteinment in Historical Perspective: A Swedish-English Comparison // British Journal of Sociology. 1993. Voi.44. Xs2.P-213-247 (part I), № 3. P 403 (part II) Lipsky, D., Gartner, A. School Reform and Inclusive Education. Baltimore: Paul H/Brooks, 1996.189p. https://lib.iitta.gov.ua/724582/1/1-68.pdf

13. Lipsky, D., Gartner, A. School Reform and Inclusive Education. Baltimore: Paul H. / Brooks., 1996.189 p.

\section{РАЗВИТИЕ ИНКЛЮЗИВНОГО ОБРАЗОВАНИЯ В УКРАИНЕ: ОСОБЕННОСТИ ПРОВЕДЕНИЯ ВСЕУКРАИНСКИХ ЭКСПЕРИМЕНТОВ 2001-2019 ГГ.}

\author{
Коноз Оксана, \\ ORCID iD 0000-0003-0443-9531 \\ аспирантка кафедры дошкольного образования \\ Николаевский национальный университет \\ имени В. А. Сухомлинского \\ ул. Никольская, 24, 54000, г. Николаев, Украина \\ konozoksana77@gmail.com
}


В статье раскрыты условия внедрения и реализаџии инклюзии в Украине в начале XХІ века путем проведения Всеукраинских научно-педагогических экспериментов. Проведен сравнительный анализ научно-педагогических экспериментов: 1) обучение лии с особыми образовательными потребностями в интегрированных условиях 2001-2007 г2. «Социальная адаптация и интеграция в общество детей с особенностями психофизического развития методом организации их обучения в общеобразовательных учреждениях»; 2) 2008-2013 г2. "Социальная адаптация и интеграция в общество детей, которые нуждаются в коррекции физического (или) умственного развития, методом организации их инклюзивного образования» для определения результатов и их влияния на развитие инклюзивного образования в Украине; 3) 2016-2019 г2. «Развитие инклюзивной образовательной среды в Запорожской области».

Описана иель проектов: усиление отношения государства, учреждений образования и негосударственных организачий, механизмы регулирования, законодательные нормативные документы внедрения инклюзивного образования. Указаны организаторы-партнеры, направления, финансирование, результатьл. Доказана динамика роста количества привлеченных детей с особыми образовательными потребностями, роста инклюзивных школ, классов (групп), увеличение ассистентов учителей. Приведены примеры модернизации образовательной отрасли путем обеспечения инклюзивной образовательной среды и проблемы развития: обучение педагогов, общественное мнение, неготовность педагогических работников к работе с лицами с ООП, недостаточное финансирование, отсутствие ориентации компетентностей, необходимьх для дальнейшей самостоятельной жизни, в программах детей для ООП, неосведомленность об отечественном и зарубежном опыте работы с лицами с ООП. Научной новизной является сравнение модернизаџий и реформ в образовательной отрасли с внедрением инклюзивного обучения, получение механизмов предоставления услуг детям с ООП - психолого-педагогического сопровождения и коррекционно-развивающих занятий.

Ключевые слова: дети с особенными образовательными потребностями; инклюзивное обучение; инклюзия; модернизаџия; реформирование.

\title{
DEVELOPMENT OF INCLUSIVE EDUCATION IN UKRAINE: ALL-UKRAINIAN EXPERIMENTS 2001-2019
}

\author{
Konoz Oksana, \\ postgraduate student of the Preschool Education Department \\ Mykolaiv National University named after V. O. Sukhomlynskyi, \\ Mykolaiv In-Service Teachers Training Institute, \\ 24 Nikolska Street, 54000, Mykolaiv, Ukraine \\ konozoksana77@gmail.com
}

The article discloses the preconditions for implementation of inclusive education in Ukraine at the beginning of the XXI century by conducting All-Ukrainian scientific and pedagogical experiments. There is a comparative analysis of such pedagogical experiments: 1) teaching people with special educational needs in integrated conditions, 2001-2007. "Social adaptation of children with special psychophysical development by including them into the learning process of educational institutions»; 2) 2008-2013. "Social adaptation of children who need correction of physical or mental development by their inclusive education» The goal is to determine the results and impact on the development of inclusive education in Ukraine; 3) 2016-2019. "Development of an inclusive educational environment in the Zaporizhia region.»

The project's purposes are strengthening the relationship between the state, educational institutions and non-governmental organizations, developing regulatory mechanisms and legislative documents for inclusive education. The partners, directions of development, 
financing, and results are indicated. There are dynamics of the number of involved children with special educational needs, number of inclusive schools and classes, and teacher assistants. Examples of the modernization of the educational industry by providing an inclusive educational environment are given. There are issues listed such as teacher training, public prejudices, insufficient funding, lack of the competencies for further independent children's life.

Keywords: children with special educational needs (CEN); inclusion; inclusive learning; modernization; reform.

\section{REFERENCES}

1. Budiak, L. V. (2010). Inkliuzyvne navchannia v silskomu zahalnoosvitnomu zakladi [Inclusive education in a rural secondary school]. (Extended abstract of candidate's thesis). In-t spets. pedahohiky NAPN Ukrainy. K. Retrieved from: https://cuti.cc/kkgrg (ukr).

2. But, T. (2015). Indeks inkliuzii: rozvytok navchannia ta uchasti $v$ zhyttiediialnosti shkil [Index of inclusion: the development of learning and participation in school life].Trans. from eng. K.: TOV Vydavnychyi dim «Pleiady». Retrieved from: http://ussf.kiev.ua/ieeditions/264/ (ukr).

3. Jonson J., Mill C., Muller W. (1993). Social Class and Educational Atteinment in Historical Perspective: A Swedish-English Comparison// British Journal of Sociology. 1993. Voi.44. Xs2.P-213-247 (part I), № 3. P 403 (part II) (eng).

4. Kolupaieva, A. A. (2009). Inkliuzyvna osvita: realii ta perspektyvy [Inclusive education: realities and prospects]. Kyiv: «Sammit-Knyha». [Elektronnyi resurs]. Retrieved from: https:// www.studmed.ru/kolupayeva-aa-nklyuzivna-osvta-realyi-ta-perspektivi $7 \mathrm{ff} 11 \mathrm{de} 2 \mathrm{f} 67 . \mathrm{html}$. (ukr).

5. Kolupaieva, A. A. (2014). Inkliuzyvna osvita yak model sotsialnoho ustroiu [Inclusive education as a model of social order]. Osoblyva dytyna: navchannia $i$ vykhovannia, $2,7$. [Elektronnyi resurs]. Retrieved from: https://core.ac.uk/download/pdf/159118815.pdf. (ukr).

6. Kudiarska, T. R. (2021). Eksperymentalne doslidzhennia sformovanosti hotovnosti maibutnikh pedahohiv zakladiv doshkilnoi osvity do vprovadzhennia aktyvnykh form pedahohichnoi vzaiemodii $\mathrm{v}$ umovakh inkliuzyvnoho navchannia [Experimental study of the formation of the readiness of future teachers of preschool education to implement active forms of pedagogical interaction in the context of inclusive education. Herald of Pedagogy]. Herald Pedagogiki. Nauka i Praktyka, 67. ISSN: 2450-8160 (ukr).

7. Lipsky D., Gartner, A. School Reform and Inclusive Education. Baltimore: Paul H. / Brooks., 1996.189 p. https://lib.iitta.gov.ua/724582/1/1-68.pdf. (eng).

8. Lorman, T., Deppeler, D. \& Kharvi, D. (2010). Inkliuzyvna osvita. Pidtrymka rozmaittia u klasi [Inclusive education. Supporting diversity in the classroom]. Kyiv: SPD-FO Parashyn I. S. (ukr).

9. National doctrine of education development in Ukraine in the 21st century. Education Reform Strategy Support Program, Kyiv: International. Renaissance Foundation, 2001, 2-6. [Electronic resource]. Retrieved from: https://zakon.rada.gov.ua/laws/show/347/2002\#Text (ukr).

10. Shipicyna, L. M. (2004). Integracija detej s ogranichennymi vozmozhnostjami zdorov'ja [Integration of children with disabilities]. Vospitanie i obuchenie detej s narushenijami razvitija, 2, 7-10 (rus).

11. Tarasun, V. V. (2017). Osnovy teorii i praktyky lohodydaktyky [Fundamentals of the theory and practice of $\log$ didactics]. K.: «Karavela», 316 s. (ukr).

12. Tymchyk, O. \& Zhukova, Yu. (2021). Formuvannia inkliuzyvnoho prostoru $v$ suchasnomu universyteti : indyvidualizatsiia ta unifikatsiia [Formation of inclusive space in a modern university: individualization and unification]. OD, vyp. 32, vyp. 1, 69-86, Liut.2021. DOI: https://doi.org/10.28925/2312-5829.2021.1.5. (ukr).

13. Zasenko, V. V. (2002). Rivnyi dostup do yakisnoi osvity ditei z osoblyvymy potrebamy [Equal access to quality education for children with special needs]. Kroky do demokratychnoi osvity, 1, 34 (ukr). 